\section{The Effects of Dependence on Brazilian Third-Party Logistics Satisfaction}

\author{
Os Efeitos da Dependência na Satisfação dos Operadores Logísticos \\ Brasileiros
}

\author{
Antonio Carlos Rodrigues*1 6 \\ Ricardo Silveira Martins ${ }^{2}$
}

\section{ABSTRACT}

Context: studies argue that similar levels of dependence are essential for supplier satisfaction in buyer-supplier relationships. However, asymmetric relationships can also lead to supplier satisfaction. Objective: this paper investigates the effects of benefit-based dependence (positive motivations for maintaining relationships) between buyer and supplier and supplier satisfaction. Methods: response surface analysis (RSA) was used to test the relationship between third-party logistics (3PL) dependence and satisfaction dimensions in 174 dyads. Results: the results demonstrated that about supplier satisfaction, instead of dependence asymmetry what really matters is the degree of dependence between the parties. The more dependent one part is on the other, usually, the greater the supplier's satisfaction. In many circumstances, a degree of dependence is acceptable and necessary to access resources and opportunities. Conclusions: the interaction between buyer and supplier dependence and supplier satisfaction is complex. Situations of dependence asymmetry in which the supplier is highly dependent on the buyer may still be satisfactory.

Keywords: dependence; satisfaction; RSA; 3PL; outsourcing.

\footnotetext{
* Corresponding Author.

1. Universidade Federal de Juiz de Fora, Faculdade de Administração e Ciências Contábeis, Governador Valadares, MG, Brazil.

2. Universidade Federal de Minas Gerais, Faculdade de Ciências Econômicas, Belo Horizonte, MG, Brazil.

Cite as: Rodrigues, A. C., \& Martins, R. S. (2022). The effects of dependence on Brazilian third-party logistics satisfaction. Revista de Administração Contemporânea, 26(1), e200380. https://doi.org/10.1590/1982-7849rac2022200380.en
}

\# of invited reviewers until the decision:

$1^{\text {st }}$ round
$2^{\text {nd }}$ round
$3^{\text {rd }}$ round
$4^{\text {th }}$ round

\section{RESUMO}

Contexto: estudos argumentam que níveis de dependência similares são essenciais para a satisfação do fornecedor nas relaçóes comprador-fornecedor. Contudo, relaçóes assimétricas também podem levar à satisfação do fornecedor. Objetivo: este artigo investiga quais os efeitos da dependência baseada em benefícios (motivaçóes positivas para manter relacionamentos) entre comprador e fornecedor e a satisfação do fornecedor. Métodos: utilizouse a análise de superfície de resposta (ASR) para testar a relação entre as dimensóes da dependência e da satisfação do operador logístico (OL) em 174 díades. Resultados: os resultados demonstram que com relaçâo à satisfação do fornecedor, não é tanto a assimetria de dependência que importa, mas sim o grau de dependência entre as partes. Quanto mais dependente uma parte for da outra, normalmente, maior será a satisfaçáo do fornecedor. Certo grau de dependência é aceitável e, em muitas circunstâncias, necessário para se ter acesso a recursos e oportunidades. Conclusóes: a interaçáo entre a dependência do comprador e do fornecedor e a satisfação do fornecedor é complexa. Situaçóes de ocorrência de assimetria de dependência em que o fornecedor é altamente dependente do comprador, ainda assim, podem ser satisfatórias para os fornecedores.

Palavras-chave: dependência; satisfação; ASR; operador logístico; terceirização.
JEL Code: M1, M10, M11.

Editor-in-chief: Wesley Mendes-da-Silva (Fundação Getulio Vargas, EAESP, Brazil) (]) Reviewers: Priscila Laczynski de Souza Miguel (Fundação Getulio Vargas, EAESP, Brazil) Pierre Oberson de Souza (Fundação Getulio Vargas, EAESP, Brazil) [

Peer Review Report: The Peer Review Report is available at this external URL. Received: October 29, 2020 Last version received: March 22, 2021 Accepted: March 23, 2021 


\section{INTRODUCTION}

Supplier satisfaction provides strategic value to its buyers (Dwyer, Schurr, \& Oh, 1987). Satisfied suppliers invest their efforts in relationships, favoring buyers with access to the innovations and other critical resources they hold (Caniëls, Vos, Schiele, \& Pulles, 2018; Pulles, Schiele, Veldman, \& Hüttinger, 2016; Shu \& Lewin, 2017). In this way, a better understanding of the relations between drivers and situations favoring the highest level of satisfaction by the supplier about its buyers can improve both individual performance and the whole supply chain (Caniëls et al., 2018; Schwieterman, Miller, Knemeyer, \& Croxton, 2020).

In this case, interorganizational dependence has been identified as an important factor for understanding the relations between buyer and supplier (Griffith, Hoppner, Lee, \& Schoenherr, 2017; Huo, Liu, Chen, \& Zhao, 2017; Kull \& Ellis, 2016; Pfeffer \& Salancik, 1978). Some authors (Huo, Tian, Tian, \& Zhang, 2019; Kumar, Scheer, \& Steenkamp, 1995; Leonidou, Talias, \& Leonidou, 2008) tend to treat buyer-supplier relationships as characterized by a mutual dependence, that is, relations in which the buyer and supplier need each other mutually to maintain their performance outperform other types of relationships. However, dependence relationships are not always symmetrical. One partner may be more dependent on the relations established, for example, by the importance of revenues in the total budget of the business or the domain of technology. In this context of dependence asymmetry, many authors believe that relationships are less satisfactory for one partner when one of them dominates the exchange, since the dominant partner can explore his position (Casciaro \& Piskorski, 2005; Gulati \& Sytch, 2007; Huo, Flynn, \& Zhao, 2017). However, even when one buyer dominates the relationship, suppliers can still feel higher level of satisfaction with the relationship (Caniëls et al., 2018). In this sense, although the literature suggests that the dependence asymmetry leads to lower performance relationships, mainly in terms of solid interorganizational processes, it can promote relationships in which there is supplier satisfaction, leading to improvements in the performance of the dyad.

This paper focuses on the Brazilian logistics services sector to answer the following research question: What are the effects of dependence based on benefits between buyer and supplier and supplier satisfaction? Benefit-based dependence is understood to be the need to maintain the relationship because a company cannot replace the benefits that derive from the current relationship with another partner (Scheer, Miao, \&
Garrett, 2010; Vázquez-Casielles, Iglesias, \& VarelaNeira, 2017). In this study, data were collected from shippers and third-party logistics (3PLs). The logistics outsourcing industry provides a relevant context for investigating the dynamics of interdependence from the supplier's perspective. On the one hand, as 3PLs increase their service offerings' sophistication, customers are increasingly dependent on 3PLs, as they play a strategic role in their operations (Hofer, 2015; Leuschner, Carter, Goldsby, \& Rogers, 2014). On the other hand, most outsourced functions are still transactional, standardized, and repetitive and the average duration of the contract remains short, reflecting the customers' desire to maintain flexibility in their agreements with 3PLs (Fundação Dom Cabral, 2018; Hofer, 2015).

The power-dependence relations, in this study, considered two dimensions - dependence asymmetry and mutual dependence - , providing a representation of the role of power and dependence in explaining the behavior of a company in an inter-organizational relationship (Blau, 1964; Emerson, 1962). Dependence asymmetry refers to the difference in the dependence levels of actors in a dyad, placing a given actor in a condition of dependence advantage or disadvantage in the relationship (Emerson, 1962). On the other hand, mutual dependence is the sum of the dependence of each of the actors (Gulati \& Sytch, 2007). Supplier satisfaction was used as a dependent variable since supplier satisfaction is considered crucial for understanding many aspects of buyer-supplier relationships that are relevant from a managerial point of view, such as collaborative innovation, supply allocation, and behavior of supplier prices (Glavee-Geo, 2019; Pulles et al., 2016; Walter, Ritter, \& Gemünden, 2001).

Supplier relationships are an important means by which buyer access and leverage supplier resources (Prajogo, Chowdhury, Nair, \& Cheng, 2020). Supplier satisfaction is essential for this; however, although this importance is known (Glavee-Geo, 2019; Pulles et al., 2016; Walter et al., 2001), researchers point out the need to deepen knowledge about how to achieve supplier satisfaction (Ambrose, Marshall, \& Lynch, 2010; Glavee-Geo, 2019). In this article, a model of supplier dependence and satisfaction has been developed and tested in the relationship that contributes to addressing this gap.

The remainder of this paper is organized as follows. The following section presents the theoretical framework and the tested hypotheses. This section is followed by another containing the data and the methodology. The empirical results are then presented and discussed in terms of managerial implications in the following two 
sections, while the conclusions are outlined in the final section.

\section{THEORETICAL BACKGROUND}

\section{Supplier satisfaction and dependence on buyer-supplier relationships}

Supplier satisfaction is related to the value that suppliers perceive in a relationship, in terms of meeting or exceeding his expectations (Caniëls et al., 2018; Glavee-Geo, 2019; Pulles et al., 2016). If a supplier perceives a relationship to be satisfactory in terms of benefits achieved, the supplier will feel socially indebted and make relational investments (Ambrose et al., 2010; Blau, 1964; Emerson, 1962; Nyaga, Lynch, Marshall, \& Ambrose, 2013). Ambrose, Marshall and Lynch (2010) found, for example, that, in general, suppliers perceive relationship ties more strongly than buyers. Thus, satisfied suppliers make a greater effort to gratify their customers and provide resources that go beyond what was contracted (Caniëls et al., 2018; Nyaga et al., 2013).

Supplier satisfaction, therefore, is an essential factor in obtaining the preferred customer status, which includes benefits for buyers, such as better access to innovations and technologies, greater flexibility, and access to resources in times of scarcity (Benton \& Maloni, 2005; Pulles et al., 2016; Walter et al., 2001). Thus, supplier satisfaction is positively related to the relational performance of buyers and suppliers. On the other hand, suppliers who are not satisfied with their relationship may, eventually, look for alternatives and commit to other relationships (Scheer, Miao, \& Palmatier, 2015). For this reason, dissatisfied suppliers can lead to lower performance within the buyer-supplier relationship, reducing their long-term competitive advantages. Supplier satisfaction is an element of strategic value for purchasing companies (Caniëls et al., 2018).

Buyers and suppliers, in turn, are dependent on each other for the resources and results they value in the relationship. Cook, Cheshire and Gerbasi (2006), for example, argue that within a relationship, the satisfaction of the actors with the relationship itself is one of the most important factors in determining its quality and potential results. Likewise, Caniëls, Vos, Schiele and Pulles (2018) argued that supplier satisfaction is critical to the supply chain's collective success because the results of the buyer-supplier relationship are highly dependent on the supplier's initiatives. Thus, relational exchanges are primarily influenced by the dependence structures of the relationship (Blau, 1964; Emerson, 1962; Molm, 1991). Thus, this paper argues that buyer-supplier dependence is a determinant of supplier satisfaction. The theoretical foundations of dependence can be extracted from Emerson's (1962) power-dependence theory and from the resource dependence theory by Pfeffer and Salancik (1978). The basic idea of these theories is that organizations are interconnected systems that need resources for survival. The need for these resources presupposes dependence and power relationships in interorganizational relationships.

Although the definitions vary considerably, a general definition of dependence is "the need for an actor to continue his relationship with an exchange partner to achieve his desired goals" (Scheer et al., 2015, p. 700). Many researchers have built studies based on Emerson's (1962) insights, operationalizing dependence, focusing on factors associated with a motivational investment in the current relationship and availability of alternatives to that relationship (Casciaro \& Piskorski, 2005; Gulati \& Sytch, 2007; Hofer, 2015; Kumar et al., 1995).

In this study, we used the classic conceptualization of dependence by Emerson (1962) and the twodimensional dependence model by Scheer, Miao and Garrett (2010). For Emerson (1962), interdependence is composed of mutual dependence, or the sum of the actors' dependencies, the dependence asymmetry, or the difference in the dependencies of the actors. Emerson (1962) labeled these constructs 'cohesion' and 'dependence advantage,' respectively. The term 'dependence advantage' is used to specify the directionality of dependence asymmetry in the dyad and indicate which of the two actors has the dependence or power advantage. The structural dichotomy allows the dependence to vary simultaneously in both dimensions, treating the dependence as a non-zero-sum game.

Thus, the approach used in this study provides a more accurate understanding of the dependence asymmetry and mutual dependence. Unlike scholars who have examined power asymmetry (Nyaga et al., 2013) and interdependence (Gulati \& Sytch, 2007), bringing them together allows the observation of existing interactions between dimensions (Casciaro \& Piskorski, 2005; Crook, Craighead, \& Autry, 2017). For this reason, although the dependence asymmetry can generate negative results for the actor in a position of power disadvantage, higher levels of mutual dependence can provide different results (Crook et al., 2017; Handley, Jong, \& Benton, 2019; Huo, Flynn, et al., 2017). For example, Griffith, Hoppner, Lee and Schoenherr (2017) analyzed the resource sharing of suppliers and found that positive and negative inequalities differentially influence the relationship's perceived performance, depending on the degree of mutual dependence. In summary, the 
article demonstrates the importance of the dependence dyadic view, explicitly considering the different effects of dependence asymmetry and mutual dependence between buyer and supplier. Thus, the interorganizational dependence study requires the adoption of a bilateral view, taking into account the buyer and supplier dependence.

Kumar, Scheer and Steenkamp (1998), Scheer et al. (2010) and Vázquez-Casielles, Iglesias and Varela-Neira (2017) identify two distinct components of dependence that constitute different reasons why a part can maintain its relationship with a current partner. Benefit-based dependence is the need for a part to maintain its relationship with an exchange partner because of the irreplaceable and unique value that would be lost if that relationship ended (Scheer et al., 2010; 2015). Cost-based dependence is the need to maintain the relationship with a specific partner due to the unrealized costs incurred if the relationship ended (Scheer et al., 2010). Each component captures different aspects of the part's motivational investment in the current relationship and its availability of alternatives (Kumar, Scheer, \& Steenkamp, 1998; Scheer et al., 2015; Vázquez-Casielles et al., 2017). While the dependence on benefits is based on the net value received from the current relationship and to the extent that this value cannot be replicated through the next best alternative, the dependence on costs is based on the anticipated costs of terminating and breaking up the current relationship, plus the projected costs to research, track, evaluate, select, request, initiate, and transition to the next best alternative (Scheer et al., 2010). Benefit-based dependence is concentrated in the present, while cost-based dependence is concentrated on the potential future that manifests when the relationship ends (Kumar et al., 1998; Scheer et al., 2010; 2015). In this study, pure scales of benefit-based dependence were used, unlike Caniëls et al. (2018), as the receipt of exclusive benefits provides satisfaction to maintain the relationship. However, the supplier may still be motivated to analyze competitive offers in search of better positioning to negotiate future purchases (Scheer et al., 2010). Thus, this research advances the literature by differentiating the importance of dependence in the supply chain context. Use in just one dimension of dependence may be appropriate when the theory indicates that the focal construct is only benefit-based dependence or cost-based dependence (Scheer et al., 2015; VázquezCasielles et al., 2017).

\section{Mutual dependence and satisfaction in buyer-supplier relationships}

No company fully controls all the conditions necessary to obtain a desired result and, therefore, every company needs others to provide vital resources (Hillman, Withers, \& Collins, 2009; Pfeffer \& Salancik, 1978). Dependence studies generally conceptualize relationships in dyads, taking into account buyer and supplier dependence (Caniëls et al., 2018; Griffith et al., 2017; Kumar et al., 1995). The ownership or control of critical assets by one part creates dependence on the other part; thus, A has a dominant position over B if B depends on A more than A depends on B (Blau, 1964; Emerson, 1962). In the literature, the balance in dependence levels between partners increases the relationship's stability (Casciaro \& Piskorski, 2005; Gulati \& Sytch, 2007). The social exchange theory (SET) suggests that exchanges between partners occur when they are rewarding for both parties (Emerson, 1962). In this sense, buyer-supplier relationships characterized by mutual dependence facilitate interactions between companies that seek to create and capture value. Dependence studies describe notions such as 'total interdependence,' 'mutual dependence,' or 'joint dependence' (Casciaro \& Piskorski, 2005; Gulati \& Sytch, 2007; Hofer, 2015) to describe the sum of the parties' dependence. Higher levels of mutual dependence increase the intensity of economic interaction between exchange partners and are related to a stronger and longer-term relational orientation (Gulati \& Sytch, 2007). Therefore, these relationships are expected to be stable and beneficial to both parties.

Figure 1 shows the relationship between buyer and supplier dependence. The solid diagonal line refers to a situation where buyers' dependence is equal to the dependence on suppliers. In cases of symmetrical dependence, relationships may differ about mutual dependence. The buyer-supplier relationship can be characterized by a low or high mutual dependence, each of which has behavioral implications for the relationship. Low levels of mutual dependence, for example, reflect relationships with buyers who are concerned with routine non-critical products with little value per unit. 


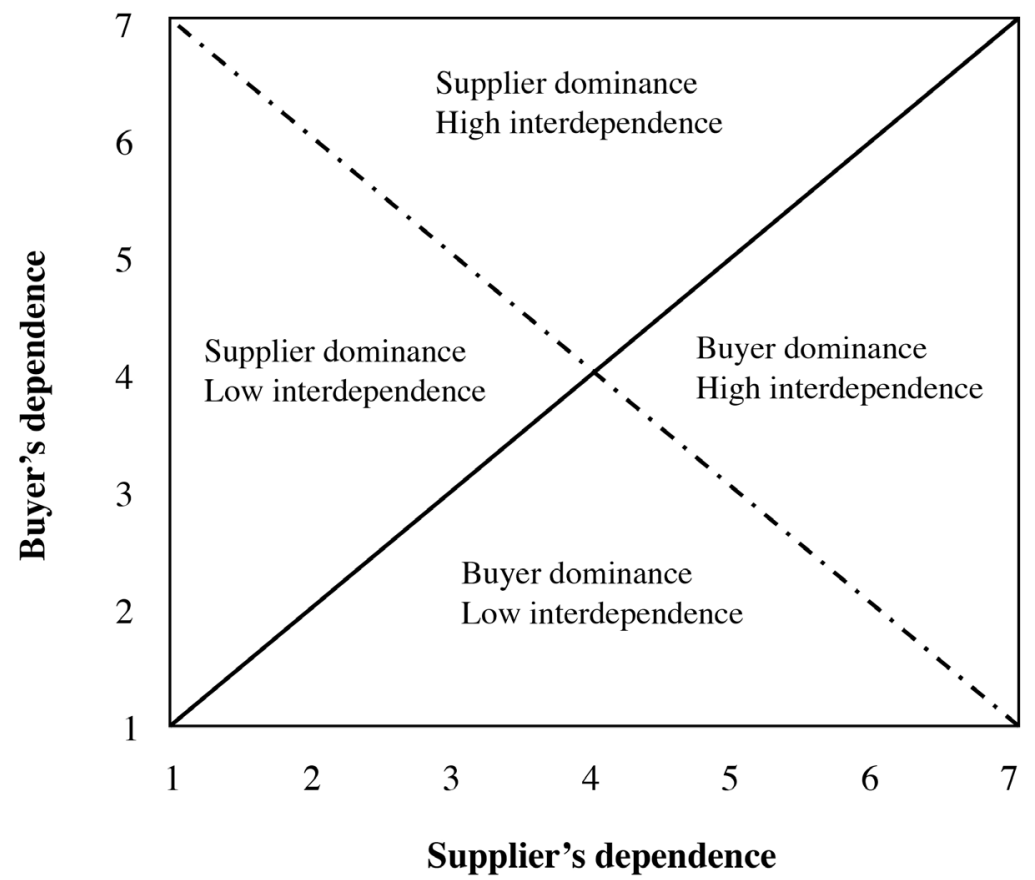

Figure 1. Buyer-supplier dependence dynamics.

The solid line indicates situations of symmetrical dependence between the parties; the dashed line indicates situations of dependence asymmetry. Source: Adapted from Caniëls et al. (2018).

The risk of retaliation is considered very high by the parties (Gulati \& Sytch, 2007). Therefore, the degree of the mutual dependence of the relationship can be expected to positively influence the partners' behavior to continue the exchange, avoiding relational risks due to the value generated by the relationship (Casciaro \& Piskorski, 2005; Gulati \& Sytch, 2007; Hofer, 2015; Manders, Caniëls, \& Ghijsen, 2017). Thus, “... higher levels of [joint] mutual dependence necessarily increase the depth of economic interaction between exchange partners, initiating a stronger relational orientation" (Gulati \& Sytch, 2007, p. 33). In this sense, the relationship's benefits in the present, such as concentration of sales/profit, representativeness of the partner, and access to resources, create dependence between the parties (GlaveeGeo, 2019; Pulles et al., 2016; Walter et al., 2001). Because of the desire to continue the relationship and the perception of high dependence on the partner, both sides will likely renounce the use of their power. The risk of retaliation is considered very high by the partners (Casciaro \& Piskorski, 2005; Gassenheimer \& Ramsey, 1994; Gulati \& Sytch, 2007; Reimann \& Ketchen, 2017). Therefore, the degree of mutual dependence on the relationship can be expected to positively influence the partners' behavior to continue the exchange, avoiding relational risks due to the value generated by the exchange that both partners perceive. Relationships in which the buyer and the supplier are mutually dependent at a high level are more likely to generate high supplier satisfaction levels. Consequently, hypothesis $1 \mathrm{a}$ is defined:

Hypothesis 1: Higher level of mutual benefitbased dependence is positively related to supplier satisfaction.

\section{Dependence asymmetry and satisfaction in buyer-supplier relationships}

Above the solid diagonal line in Figure 1, buyers' dependence is greater than that of suppliers; therefore, we have an asymmetric relationship dominated by the supplier. Likewise, below the diagonal, there is a situation of buyer dominance. Dependence asymmetry is generally associated with a negative influence on performance, reducing the willingness to compromise or adapt (Casciaro \& Piskorski, 2005; Gundlach \& Cadotte, 1994). In asymmetric relationships, a partner dominates the exchange (Casciaro \& Piskorski, 2005; Gulati \& Sytch, 2007; Hofer, 2015; Huo, Flynn, et al., 2017; Kim \& Choi, 2018). Current views dictate that these relationships are less effective because the dominant partner may be tempted to exploit his position (Crook \& Combs, 2007; Crook et al., 2017; Ireland \& Webb, 2007). Generally, the mere presence of asymmetric 
positions in relationships is associated with instability and conflict (Kumar et al., 1995; Nyaga et al., 2013).

If the relationship's continuity is not a priority, the dominant partner can appropriate the greater part of the created relational value (Brito \& Miguel, 2017; Crook \& Combs, 2007). Usually, if the supplier is the dominant part of the relationship, the supplier is likely to capture more value, leading to greater satisfaction. Suppliers' value in a relationship creates a feeling of satisfaction about investments in relationships and, therefore, is linked to supplier satisfaction (Benton \& Maloni, 2005; Crook \& Combs, 2007; Pulles et al., 2016). Therefore, relationships in which the supplier has a dominant position in terms of benefit-based dependence are more likely to lead to higher supplier satisfaction levels. As a result, hypothesis 2 is structured:

Hypothesis 2: Supplier satisfaction is greater when the supplier's benefits-dependence is less than the buyer.

On the other hand, the buyer dominance does not necessarily result in the supplier's lack of satisfaction. Many suppliers are highly dependent on large buyers, but not all of these relationships create conflicts, and suppliers do not always seek to reduce the vulnerability in those relationships (Caniëls et al., 2018). Also, buyer companies do not necessarily exploit dependence on suppliers, which would limit the negative consequences of dependence asymmetry (Crook et al., 2017). Studies show that the abuse of a dominant position by the buyer can have a negative impact on the relationship's value-generating performance (Casciaro \& Piskorski, 2005; Gulati \& Sytch, 2007; Huo, Wang, Zhao, \& Schuh, 2016). Thus, the non-use of power positively influences supplier satisfaction (Crook et al., 2017; Gaski, 1984).

On the other hand, even if a dominant buyer extracts a higher relative value from a relationship, the supplier can still be satisfied due to the absolute value that the supplier perceives (Caniëls et al., 2018). Even if a relationship is not symmetrical in terms of dependence, high levels of absolute value can still result in supplier satisfaction. For example, when comparing a symmetrical relationship with a small partner with a low churn potential and an asymmetric relationship with a significant partner with a high churn potential, a supplier may prefer to cooperate with the larger partner to assume the highest churn potential - accepting the relative dependence according to the benefits generated. In these situations, suppliers tend to satisfy the need for large volume orders for their survival, despite the buyer's relative domain (Brito \& Miguel, 2017). Therefore, at moderate levels of mutual dependence, even in the presence of dependence asymmetry, this type of relationship can lead to greater supplier satisfaction. In this sense, the dependence asymmetry has a positive effect on supplier satisfaction. Under these conditions, hypothesis 3 is structured:

Hypothesis 3: At moderate levels of mutual benefitdependence, supplier and buyer dominance is positively related to supplier satisfaction.

\section{METHODOLOGY}

Data from this study were collected through a survey of 3PLs in Brazil to answer the proposed research question. A survey is appropriate because the dimensions and scales for measuring supplier dependence and satisfaction are well developed and do not need to be created but tested to extend the existing theory (Benton \& Maloni, 2005; Gulati \& Sytch, 2007; Hofer, 2015; Scheer et al., 2015). The 3PL industry provides a relevant context for the research for the following reasons: (a) it is a service and, therefore, the effects of dependence tend to be more significant than in relationships that focus on goods supply (Scheer et al., 2015); (b) logistics costs are relevant in Brazil, since two thirds of the expenses of companies with logistics are directed to the payment of 3PLs (ILOS, 2014), a reality similar to that of Europe and the United States, where about half of the expenses are used for this purpose (Hofer, 2015; Lieb \& Lieb, 2016); (c) it presents an important dependence dynamic in relations because 3PLs have a strategic role in their customers' operations (Marasco, 2008; Scheer et al., 2015); (d) the industry has a relevant potential for building long-lasting relationships, given the complexity of the services due to their nature, as well as the level of customization required in solving problems (Hofer, 2015; Lieb \& Lieb, 2016); and, finally, (e) dependence relationships between firms permeate the creation of value, despite the occurrence of dependence asymmetry mechanisms generated by a scenario of reduced margins (Hofer, 2015; Scheer et al., 2015).

The units of analysis of this research are the dyads between buyers and suppliers (Forza, 2002). The relationships developed by 3PLs and their customers were taken as a reference. Thus, this study starts from the supplier's perspective to analyze the buyer-supplier relationship. The supplier's view of the relationship is especially interesting, as the supplier can better assess the effects of using power. The same pattern can be found in other studies in the literature, which also used the supplier's perspective to analyze the relationship between buyer and supplier (Casciaro \& Piskorski, 2005; Gulati \& Sytch, 2007; Huo, Flynn, et al., 2017).

The fact that only one side of the relationship accounts for the dyad can lead to questions about this measurement's accuracy. However, this bias is reduced because, as shown 
by some meta-analytical studies (Bauman \& Dent, 1982; Farh, Werbel, \& Bedeian, 1988), artificial responses tend to occur in contexts where there is some reward linked to the responses (Flynn, Pagell, \& Fugate, 2018; Forza, 2002). Thus, we believe in the reliability of the data for the study of the proposed phenomenon. Finally, for subsequent analyses, shipper-3PL relationships refer to buyer-supplier relationships. The shipper represents a legal entity that hires the services of a $3 \mathrm{PL}$.

\section{Sampling}

The research database was prepared using secondary sources from the main publications, magazines, and yearbooks in the 3PL Brazilian industry. There are currently no official statistics for understanding the role of the provision of logistical services in Brazil. One of the factors responsible for this result is the lack of a regulatory framework; that is, 3PLs are not provided for in the National Classification of Economic Activity (CNAE). Thus, defining the size of the sector is a difficult task. To solve this problem, the criterion used by this study for classification was the presence of CNAEs of minimum services that a 3PL must offer: CNAE 49.30-2 - Road Transport, under which transport services and CNAE are billed; and 52.11-7 — General Warehouses (Warrant Issuance), under which the services of storage and related activities and support or value-added services are billed. In this way, data (address, telephone, website, and email) were collected from 790 companies listed by specialized magazines and other secondary sources.

Qualtrics ${ }^{\circledR}$ was the platform used for the preparation and distribution of the questionnaire for this study. Initially, respondents were accessed by email, with subsequent telephone contact by relevant 3PLs to reinforce the invitation. The use of two contact routes was intended to increase the response rate. The survey respondents were professionals from the companies' commercial sector, such as commercial, sales or marketing managers or directors, or even presidents or vice presidents. To capture relationships between 3PLs and shippers with a relative level of mutual dependence, each 3PL chose one of the top three shippers in the portfolio. The participants were instructed that "all questions must be answered about your company's relationship with the selected shipper." Of the total number of 3PLs accessed, 174 returned the questionnaire, indicating a response rate of $21.9 \%$. Only one response per respondent was allowed. The characteristics of the sample are shown in Table 1.

Table 1. Sample description $(n=174)$.

\begin{tabular}{|c|c|c|c|}
\hline Demographic information & & Frequency & Percentage \\
\hline \multirow{6}{*}{ Position } & Director & 60 & $34.48 \%$ \\
\hline & Manager & 46 & $26.44 \%$ \\
\hline & President or Vice President & 41 & $23.56 \%$ \\
\hline & Coordinator & 13 & $7.47 \%$ \\
\hline & Seller & 7 & $4.02 \%$ \\
\hline & Supervisor & 7 & $4.02 \%$ \\
\hline \multirow{5}{*}{ Time working with the specific client } & Less than 2 years & 29 & $16.67 \%$ \\
\hline & Between 2 and 5 years & 42 & $24.14 \%$ \\
\hline & Between 5 and 10 years & 40 & $22.99 \%$ \\
\hline & Between 10 and 15 years & 32 & $18.39 \%$ \\
\hline & More than 15 years & 31 & $17.82 \%$ \\
\hline \multirow{5}{*}{ Revenues } & Less than $\mathrm{R} \$ 2.4$ million & 33 & $18.97 \%$ \\
\hline & From $\mathrm{R} \$ 2.4$ million to $\mathrm{R} \$ 16$ million & 71 & $40.80 \%$ \\
\hline & From $\mathrm{R} \$ 16$ million to $\mathrm{R} \$ 90$ million & 53 & $30.46 \%$ \\
\hline & From $\mathrm{R} \$ 90$ million to $\mathrm{R} \$ 300$ million & 12 & $6.90 \%$ \\
\hline & Greater than $\mathrm{R} \$ 300$ million & 5 & $2.87 \%$ \\
\hline \multirow{5}{*}{ Customer size compared to $3 \mathrm{PL}$} & Larger & 34 & $19.54 \%$ \\
\hline & Smaller & 4 & $2.30 \%$ \\
\hline & Same size & 11 & $6.32 \%$ \\
\hline & Much bigger & 117 & $67.24 \%$ \\
\hline & Much smaller & 8 & $4.60 \%$ \\
\hline
\end{tabular}

Note. Source: The authors. 
Respondent's profile corresponds to professionals in the position of director, management, or presidency in the company $(84 \%)$. The data show that $47 \%$ of the respondents have a professional experience of two to ten years with a chosen shipper. The respondents' predominance was 3PLs with average annual sales between $\mathrm{R} \$ 2.4$ million and $\mathrm{R} \$ 90$ million (see Table 1). According to the Brazilian Development Bank (BNDES), which classification is based on the companies' annual gross sales, $71 \%$ of the study's firms are considered small or medium. Compared to 3PLs, shippers' relative size was relatively much bigger $(67 \%)$ or larger 3PLs (19\%).

\section{Measures and instrument for data collection}

The development of measurement scales was composed of two phases. First, the items were obtained from a comprehensive review of the literature. Second, a round of Q-Sort was carried out to evaluate the reliability and validity of the scales, corresponding to the pre-test stage of the questionnaire. Five respondents with professional and academic experience in the supply chain analyzed the constructs and items regarding their constitutive definition, wording, and order of importance, in addition to obtaining suggestions for the inclusion of new items. The objective was to define a more parsimonious scale with four items per construct. First, the agreement convergence rates between judges were considered satisfactory (minimum $70 \%$ ), without bias. Second, the reliability of the indicators measured by the rate of convergence of items per construct reached an average of $80 \%$. Third, the minimum rate of correct allocation of items per construct was $72 \%$, higher than the minimum acceptable percentage (Moore \& Benbasat, 1991). Both analytical methods were used to increase the reliability of the development of the scales.

Two procedures were performed to control the existence of common-method variance, a concern in the cases of surveys in which the same respondent is the source of obtaining data for dependent and independent variables at the same time (Podsakoff, MacKenzie, Lee, \& Podsakoff, 2003). First, some recommendations were followed before the application of the research instrument, among them: (a) clear wording of the indicators and statements of the questions, avoiding socially desirable answers and the use of anchor words (extremely, always, never, etc.); (b) mix of indicators to avoid recurrence of indicators of the same construct; (c) conciseness and clarity in the items; (d) use of different scales and sections to assess dependent and independent variables; and (e) confidentiality of responses (Podsakoff \& Organ, 1986). Sequentially, the existence of common-method variance was also ruled out after applying the research through the Harman single-factor test (Podsakoff et al., 2003).

The measurement scales in this study were obtained from previous research. The applied questionnaire used the seven-point Likert scale to assess items that ranged from totally disagree (1) to totally agree (7). A line scale (or sliding bar) was selected to provide respondents with a greater number of positions to indicate the relative intensity of their perception (within the line length constraint). The mechanism was important for developing the constructs of relative dependence with a certain degree of variability indispensable in this research. The slider bar is intuitive, easy to use, and allows respondents to complete a long list of items quickly and with a high degree of reliability.

We tested the reliability, the discriminant validity, and the convergence of our data. The principal component analysis (PCA) was first conducted to examine whether the items were grouped in the previously selected constructs (Hair, Black, Babin, \& Anderson, 2014). We applied oblique rotations. The factors were identified based on eigenvalues greater than one. Three components were extracted from the principal component analysis, covering variations of $26 \%$, $22 \%$, and $20 \%$. All factorial loads were above the suggested minimum limit of 0.4 (Tabachnick \& Fidell, 2012), and no relevant cross-loads in non-hypothetical components were found. Then, the linearity assumption of the data and the independence of residues were tested. When regressing the independent variables on supplier satisfaction (using the OLS regression), residues were independent (Durbin Watson tests, $D W=2.12>1)$, but the distribution has moved away from normality (Shapiro Wilk Test, $W(174)=$ $0.939 ; p<0.01$ ) (Tabachnick \& Fidell, 2012).

Table 2 shows all the items that were used after the purification process. The composite reliability (CR) index of all constructs reached generally acceptable levels above 0.7 in all cases (Hair et al., 2014). Convergent validity was used based on the average variance (AVE). Two constructs had AVE greater than or equal to 0.5 , indicating convergent validity (Hair et al., 2014; Kline, 2011). The convergent validity of the 3PL benefit-dependence construct was close to this limit and was therefore considered satisfactory. Finally, the discriminant validity was tested by checking the difference between the $\chi^{2}$ statistic of a nested model (when the correlation between the constructs is equal to one) and the models where the correlation between the constructs is free (Bagozzi, Yi, \& Phillips, 1991). The three constructs of the study were paired, and the differences in $\chi 2$ were calculated. The results showed that the constructs are different because the difference of $\chi 2$ for all pairs was significant at $p<0.01$.

Table 3 presents mean, standard deviation, and correlation of the constructs. 
Table 2. Constructs and attributes for dependence and relationship satisfaction.

\begin{tabular}{|c|c|c|}
\hline Constructs & Items & $\begin{array}{c}\text { Factoria } \\
\text { loads }\end{array}$ \\
\hline \multirow{4}{*}{$\begin{array}{c}\text { 3PL benefit-based dependence } \\
\text { AVE }=0.46 \\
\text { CR }=0.76 \\
\text { (Scheer, Miao, \& Garrett, 2010; } \\
\text { Kumar, Scheer, \& Steenkamp, } \\
\text { 1995) }\end{array}$} & $\begin{array}{l}\text { Our company receives benefits for doing business with our partner that could not be obtained through } \\
\text { our next alternative }\end{array}$ & 0.702 \\
\hline & $\begin{array}{l}\text { If we stopped doing business with our partner, our products/services would be less attractive to our } \\
\text { customers }\end{array}$ & 0.553 \\
\hline & If our company had to replace our partner, the alternative(s) would not be as effective & 0.814 \\
\hline & It would be difficult for our company to replenish sales and profits generated by our partner & 0.662 \\
\hline \multirow{4}{*}{$\begin{array}{l}\text { Shipper benefit-based dependence } \\
\text { AVE }=0.55 \\
\text { CR }=0.82 \\
\text { (Scheer, Miao, \& Garrett, 2010; } \\
\text { Kumar, Scheer, \& Steenkamp, } \\
\text { 1995) }\end{array}$} & $\begin{array}{l}\text { Our partner receives benefits for doing business with us that could not be obtained through our next } \\
\text { alternative }\end{array}$ & 0.647 \\
\hline & $\begin{array}{l}\text { If our partner stopped doing business with us, his products/services would be less attractive to his } \\
\text { customers }\end{array}$ & 0.834 \\
\hline & If our partner had to replace us, his alternative(s) would not be as effective & 0.698 \\
\hline & It would be difficult for our partner to replenish sales and profits generated by us & 0.789 \\
\hline \multirow{4}{*}{$\begin{array}{c}\text { 3PL relationship satisfaction } \\
\qquad \mathrm{AVE}=0.69 \\
\mathrm{CR}=0.89 \\
\text { (Benton \& Maloni, 2005; Zou, } \\
\text { Taylor, \& Osland, 1998) }\end{array}$} & The relationship performed very satisfactorily & 0.844 \\
\hline & The relationship fully met our expectations & 0.820 \\
\hline & The relationship has been very successful & 0.842 \\
\hline & The relationship with the partner was advantageous for our organization & 0.825 \\
\hline
\end{tabular}

Note. Average variance extracted (AVE), composite reliability (CR). Source: The authors.

Table 3. Mean, standard deviation, and correlation of the constructs analyzed.

\begin{tabular}{lcccc}
\hline & Mean & $\begin{array}{c}\text { Standard } \\
\text { deviation }\end{array}$ & 1 & 2 \\
\hline $1-3$ PL benefit-based dependence & 5.85 & 1.17 & 1.00 \\
2 - Shipper benefit-based dependence & 3.91 & 1.58 & 0.307 & 1.00 \\
$3-3$ PL relationship satisfaction & 4.02 & 1.63 & 0.098 & 0.282 \\
\hline
\end{tabular}

Note. Source: The authors.

\section{Response surface analysis (RSA)}

The present study used polynomial regression and response surface analysis (Barranti, Carlson, \& Côté, 2017; Schönbrodt, Humberg, \& Nestler, 2018; Shanock, Baran, Gentry, Pattison, \& Heggestad, 2010) to test the effects of dependence on supplier satisfaction. Polynomial regression provides a successful way to reveal complexities in congruence theories (Barranti et al., 2017). The general equation for testing the relations using polynomial regression is:

$Z=b_{0}+b_{1} X+b_{2} Y+b_{3} X^{2}+b_{4} X Y+b_{5} Y^{2}$, where $Z$ is the result variable, $X$ is predictor variable 1 , and $Y$ is predictor variable 2 . Thus, the result variable is regressed in relation to each of the explanatory variables $(X$ and $Y$ ), the interaction between the explanatory variables $(X Y)$, and the square of the terms $\left(X^{2}\right.$ and $\left.Y^{2}\right)$. If the polynomial regression model is significant, the three-dimensional response surface is analyzed.

RSA provides a differentiated view of the relationships between variables because it graphically represents the results in a three-dimensional space (Schönbrodt et al., 2018; Shanock et al., 2010). Traditional approaches to measuring dependence between the partners, for example, use the algebraic difference or sum between dependencies to study relationships (Gulati \& Sytch, 2007; Hofer, 2015; Kumar et al., 1995). For example, the difference between supplier dependence $\left(d_{f}\right)$ and buyer dependence $\left(d_{c}\right)$ is calculated. If in the difference between the dependence on the supplier and the buyer's dependence $\left(d_{f}-d_{c}\right)$ the buyer's dependence is greater than the dependence on the 
supplier $d_{c}>d_{f}$, there is a dominance of the relationship by the supplier. Otherwise, the zero value is allocated. On the other hand, the buyer's domain will exist when, in the difference between the buyer's dependence and the supplier's dependence $\left(d_{c}-d_{f}\right)$, the supplier's dependence is greater than the buyer's dependence $d_{f}>d_{c}$; otherwise, the zero value is registered. Mutual dependence, in turn, is obtained by adding the buyer and supplier dependencies. However, some studies have pointed out methodological disadvantages in this type of approach (Caniëls et al., 2018; Kim \& Hsieh, 2003; Schönbrodt et al., 2018; Shanock et al., 2010). The method condenses two explanatory variables (that is, buyer dependence and supplier dependence) into a single score, which reduces the amount of information available in the analysis. In this sense, completely different situations can lead to similar average scores. For this reason, the purpose of this study is to apply RSA to overcome this disadvantage of the traditional method.

Table 4. Distribution of levels of advantage and disadvantage of dependence on 3PLs.

\begin{tabular}{ccc}
\hline Groups & \multicolumn{2}{c}{ Benefit-based dependence } \\
\cline { 2 - 3 } & $\mathrm{N}$ & $32.20 \%$ \\
\hline 3PL dependence advantage & 56 & $37.90 \%$ \\
Dependence symmetry & 66 & $29.90 \%$ \\
Shipper dependence advantage & 52 & $100.00 \%$ \\
\hline Total & 174 & \\
\hline
\end{tabular}

Note. $\mathrm{N}=$ Number of cases. The dominance groups are based on the difference of half a standard deviation between the standardized scores of the two dependence constructs; for more details, see Shanock et al. (2010). Source: The authors.

Initially, it was examined how many dyads showed discrepancies between buyer dependence and supplier dependence, which would allow polynomial regressions with sufficient variation (Shanock et al., 2010). For this, the scores of dependence on buyers and suppliers were standardized. The standardized buyer dependence scores with half standard deviation above and below the standardized supplier dependence scores were coded as the supplier's domain and the buyer's domain, respectively. The intermediate scores were coded as symmetrical in relation to dependence. As shown in Table 4, the cases have a close distribution among the three groups of dependence and, therefore, it can be concluded that it makes practical sense to analyze the discrepancies between dependencies (Shanock et al., 2010).

Then, dependence on buyers and suppliers was centralized across the midpoint of their respective scales to reduce the potential risk of multicollinearity (Schönbrodt et al., 2018; Shanock et al., 2010. After that, polynomial regression was performed with 5,000 bootstrap samples and, sequentially, a three-dimensional view of the combined relationship between buyer and supplier benefitbased dependence and its effect on supplier satisfaction was generated, including significance tests of 0.05 for all subsequent analyzes. Finally, all procedures were performed using the RSA package of R software.

\section{RESULTS}

Table 5 presents the results of the polynomial regression analyses. Rather than examining the regression coefficients as would be done in a common regression analysis, if the $\mathrm{R}^{2}$ (variance in the result variable explained by the regression equation) is significantly different from zero (Edwards, 2002; Shanock et al., 2010), the results of the polynomial regression are evaluated in relation to four surface test values: $a_{1}, a_{2}, a_{3}$ and $a_{4}$. In sequence, each of the four coefficients is explained and analyzed together in Figure 2. It should be noted that the main idea behind the RSA is the visualization of the polynomial regression equation in a three-dimensional graph. 
Table 5. Response surface results for benefit-based dependence.

\begin{tabular}{cc}
\hline Variable & 3PL relationship satisfaction \\
Intercept & $5.487^{* * *}$ \\
3PL benefit-based dependence $(\mathrm{X})$ & -0.036 \\
Shipper benefit-based dependence $(\mathrm{Y})$ & $0.349^{* * *}$ \\
Mutual dependence $(\mathrm{XY})$ & -0.078 \\
$\mathrm{X}^{2}$ & 0.116 \\
$\mathrm{Y}^{2}$ & 0.092 \\
Model fit $^{2}$ & $0.10^{* * *}$ \\
Surface test & $0.313^{* * *}$ \\
Slope symmetry line $\mathrm{a}_{1}$ (Hypothesis 1) & 0.130 \\
Curvature symmetry line $\mathrm{a}_{2}$ & $-0.385^{* * *}$ \\
Slope asymmetry line $\mathrm{a}_{3}$ (Hypothesis 2) & $0.285^{* * *}$ \\
\hline Curvature asymmetry line $\mathrm{a}_{4}$ (Hypothesis 3) & \\
\hline
\end{tabular}

Note. ${ }^{* * *} \mathrm{p}<0.01,{ }^{* *} \mathrm{p}<0.05,{ }^{*} \mathrm{p}<0.1$. The coefficients $a_{1}\left(=b_{1}+b_{2}\right)$ and $a_{2}\left(=b_{3}+b_{4}+b_{5}\right)$ represent the slope of each surface along the line $X=Y$, while $a_{3}\left(=b_{1}-\right.$ $\left.b_{2}\right)$ and $a_{4}\left(=b_{3}-b_{4}+b_{5}\right)$ represent the slope of each surface along the line $X=-Y$, where $b_{1}, b_{2}, b_{3}, b_{4}$ and $b_{5}$ are the nonstandard coefficients in $X, Y, X^{2}, X Y$ and $Y^{2}$, respectively. Source: The authors.

Figure 2 shows the three-dimensional response surface of the polynomial regression. The slope and curvature of two lines represent the response surface patterns: the line of congruence (LOC) - red - and the line of incongruence (LOIC) - blue. Figure 2 can be interpreted with four surface test values along the lines $X=Y$ (LOC) and $X=-Y$ (LOIC). The slope of the line of congruence ( $X=Y$, buyer's dependence is equal to the supplier's dependence $)$ is given by $a_{1}\left(=b_{1}+b_{2}\right.$, where $b_{1}$ is the $\beta$ for buyer dependence and $b_{2}$ is the $\beta$ of the supplier dependence). Curvature along the line $X=Y$ is indicated by $a_{2}\left(=b_{3}+b_{4}+b_{5}\right.$, where $b_{3}$ is $\beta$ for the buyer dependence squared, $b_{4}$ is $\beta$ for the cross product of buyer dependence and supplier dependence, and $b_{5}$ is the $\beta$ of the squared supplier dependence). The results indicate that $\mathrm{a}_{1}$ al is significant, but $\mathrm{a}_{2}$ is not; therefore, there is a linear slope along the line of congruence (LOC). The positive value of $a_{1}$ indicates that higher levels of mutual dependence are related to higher levels of supplier satisfaction. Therefore, hypothesis 1 is supported.
The slope and curvature can assess the impact of dependence asymmetry along the line perpendicular to the line of congruence, that is, the line $X=-Y$. The results indicate that $\mathrm{a}_{3}\left(=\mathrm{b}_{1}-\mathrm{b}_{2}\right)$ and $\mathrm{a}_{4}\left(=\mathrm{b}_{3}-\mathrm{b}_{4}+\mathrm{b}_{5}\right)$ are significant (see Table 4). In this way, the data shows a slope and a curve along the line $X=-Y$. The negative value of $\mathrm{a}_{3}$ indicates that the supplier's satisfaction levels are higher when the shipper's dependence is greater than the dependence on the 3PL than vice versa. The positive value for $\mathrm{a}_{4}$, in turn, indicates a convex surface along the line of perfect asymmetry; that is, there is a U-shaped curvature along this line. Therefore, the model indicates that extreme asymmetries have a positive impact on supplier satisfaction at high mutual dependence levels. The U-shape suggests that asymmetric dependence situations are associated with greater supplier satisfaction than symmetrical dependence situations. Therefore, hypotheses 2 and 3 have been confirmed. 


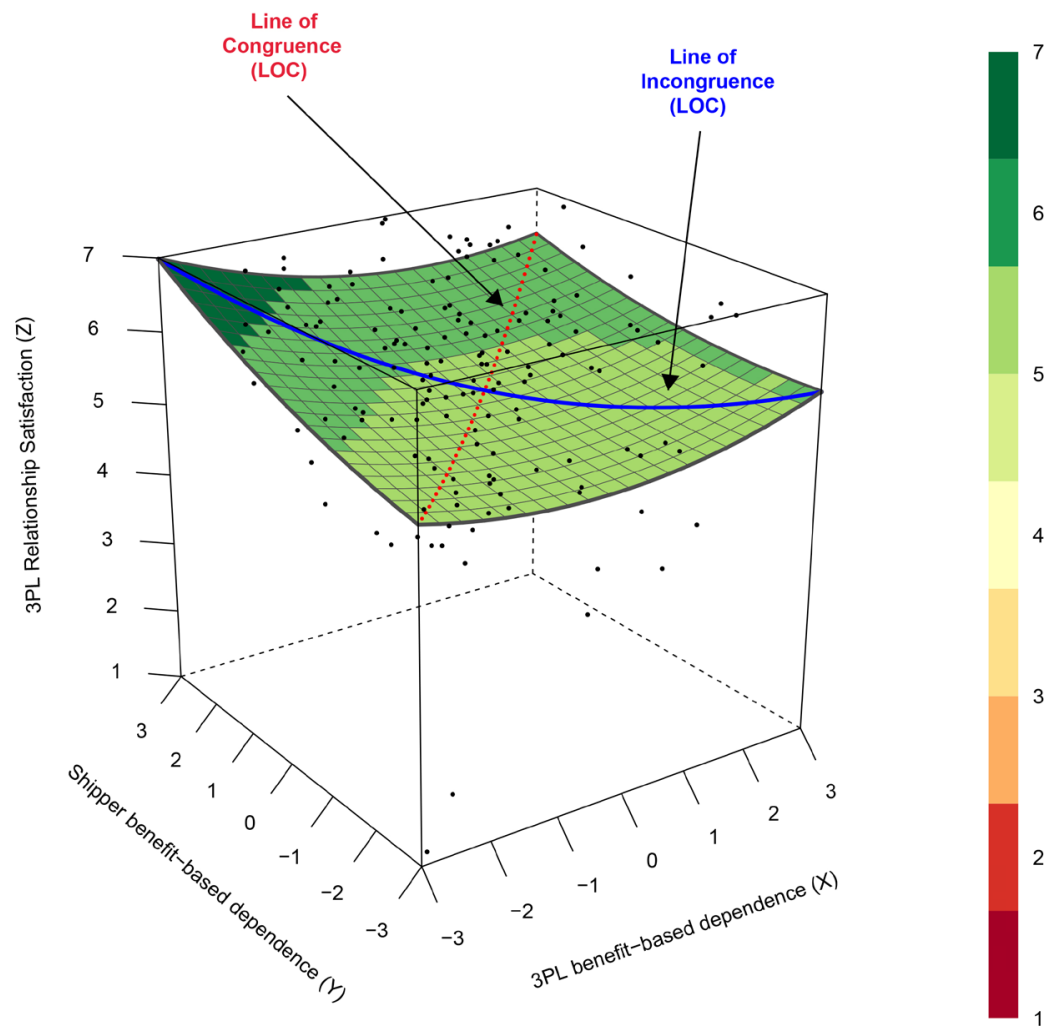

Figure 2. Response surface.

Predictors $X$ and $Y$ (3PL and shipper dependence) are centered at the scale's midpoint. In red, the Line of Congruence (LOC) reflects cases in which the values of $X$ and $Y$ correspond perfectly at all levels of the scale. In blue, the Line of Incongruity (LOIC) represents cases in which the $X$ values are perfectly opposite to the $Y$. Color legend for $Z$ values (3PL relationship satisfaction). Source: The authors.

\section{DISCUSSION AND MANAGERIAL IMPLICATIONS}

\section{Discussion}

The results showed that a high level of mutual dependence generates more supplier satisfaction (3PL), validating hypothesis 1 , supported by several previous studies (Casciaro \& Piskorski, 2005; Gulati \& Sytch, 2007; Hofer, 2015). In symmetry cases of mutual dependence between 3PLs and shippers, we found support that mutual dependence positively affects 3PL satisfaction. However, mutual dependence can be characterized as low or high, consequently leading to different 3PL satisfaction levels. The result is in line with previous studies that show that increasing levels of mutual dependence is associated with supplier satisfaction (3PL) (Caniëls et al., 2018; Gulati \& Sytch, 2007).

To the satisfaction of everyone involved in the relationship, high levels of mutual dependence between parts of the supply chain are related to some dimensions of the relationship, such as long-term orientation, integration, and collaboration (Hofer, 2015; Nyaga et al., 2013), which indicate the most remarkable propensity to develop collaborative relationships. Also, dependence has a positive impact on other dimensions of customersupplier relationships, such as trust, commitment, and conflict resolution, which, in turn, increase 3PL satisfaction (Benton \& Maloni, 2005) and reinforce the links between the actors, providing the best conditions for the development of collaborative relationships. High mutual dependence also helps prevent one part from being opportunistic and taking action for its benefit, to the detriment of the other part (Handley \& Benton, 2012; Hofer, 2015; Nyaga et al., 2013). 3PLs and shippers, in this context, maybe are even more likely to collaborate, as the provision of logistical services implies a comparatively higher degree of continuous interaction between 3PLs and shippers to create the final product (Hofer, 2015; Scheer et al., 2015). In this sense, mutual dependence plays a strategic role in the performance of operations and the 
supplier's satisfaction. Therefore, this study also reinforces previous findings that point to the beneficial effect of high levels of mutual dependence on developing collaborative actions between suppliers and customers (Caniëls et al., 2018; Casciaro \& Piskorski, 2005; Gulati \& Sytch, 2007; Hofer, 2015).

The hypothesis 2 was validated, that 3PL satisfaction is greater if $3 \mathrm{PL}$ realizes that the shipper is more dependent on the relationship. In asymmetric relationships, the most powerful partner dominates the exchange and can exploit his position of power (Crook \& Combs, 2007; Crook et al., 2017; Ireland \& Webb, 2007). Although these asymmetrical positions in relationships can lead to conflicts (Kumar et al., 1995; Nyaga et al., 2013), when the supplier has mastered the relationship, the supplier can use coercive tactics to capture greater value in the relationship at the expense of the actor least favored by dependence (Blau, 1964). In this sense, the performance benefits of the most powerful and advantageously dependent company come at the weakest partner's expense and the disadvantage of dependence (Gulati \& Sytch, 2007; Pfeffer \& Salancik, 1978). Therefore, this study confirms that when $3 \mathrm{PL}$ is the dominant part, there are higher satisfaction levels with the relationship.

For dependence asymmetry, the study also suggests that at moderate levels of mutual dependence, the extreme dependence asymmetries positively affect supplier satisfaction. The analysis of the response surface indicates that there is a U-shaped curvature along the line of incongruence (LOIC). In line with the findings of Caniëls et al. (2018), it does not matter whether the shipper dominates the 3PL or vice versa; the 3PLs are more satisfied when the shipper is highly dependent on the 3PL or when the $3 \mathrm{PL}$ is highly dependent on the shipper, validating hypothesis 3. However, the latter situation challenges the assumption of some interpretation lines present in the literature (Casciaro \& Piskorski, 2005) that the dependence on a dominant part has negative consequences for the dependent part. What are the reasons why highly dependent suppliers are still satisfied in a relationship dominated by the buyer? Although the literature supports the assumption that a part that has a dominant position in the relationship will use that position and explore the most dependent partner (Casciaro \& Piskorski, 2005; Gulati \& Sytch, 2007), in the presence of mutual dependence, the use of power can be abdicated (Caniëls et al., 2018; Crook et al., 2017). Thus, asymmetric dependence may not necessarily imply the exploitation of the dependent part. A dominant shipper can use his advantage position to benefit the relationship's capacity to generate value by providing attractive incentives, such as bonuses and financial rewards (Caniëls et al., 2018; Huo, Flynn, et al., 2017). There may be an interest in the development of suppliers and even the belief that strategically it is not interesting to promote the supplier's replacement or internalize the process. Also, a dominant shipper can provide guidance when both actors collaborate on joint tasks (Gulati \& Sytch, 2007; Huo, Flynn, et al., 2017; Nyaga et al., 2013). Caniëls et al. (2018) suggest that the non-use of power by a dominant partner leads to the dependent partner's satisfaction. Therefore, the relationship between the use of power and dependence asymmetry is less direct than traditional thinking about power (Casciaro \& Piskorski, 2005; Gulati $\&$ Sytch, 2007). The result broadens the understanding of how dependence influences buyer-supplier relationships at moderate levels of mutual dependence.

Additionally, in line with Caniëls et al. (2018), even if a dominant shipper extracts more relative value in a relationship, a 3PL can still be satisfied in a relationship due to the absolute 3PL value perceived. Instead of a symmetrical relationship with a small partner with a low turnover potential, 3PLs may prefer to cooperate with a large partner, opting for a greater turnover potential while accepting relative dependence. Given this, 3PLs can extract value from a given buyer's growth opportunities and operational excellence, such as having well-functioning planning and payment systems (Huo, Flynn, et al., 2017). The negative effects of not being the dominant part can be offset by these and other benefits generated.

Finally, response surface analysis provided a broader understanding of the complexities of the dependence relationship between supplier and customer and supplier satisfaction. The technique made it possible to use buyer dependence and supplier dependence as two distinct constructs with different measures, not reducing the available information, which is a disadvantage of traditional methods. The possibility of finding curvilinear effects made it possible to distinguish situations of asymmetric and symmetrical dependence at the same level of mutual dependence. This type of analysis is not possible with other techniques.

\section{Managerial implications}

In the managerial perspective, the dependence on a business partner is usually perceived as a situation that must be avoided. This study, however, demonstrates that in relation to supplier satisfaction, it is not so much the dependence asymmetry that matters, but the degree of dependence between the parties. The more dependent one part is on the other, usually, the greater the supplier's satisfaction. Therefore, vehemently avoiding dependence may not necessarily be the best option in all cases. A certain degree of dependence is acceptable and, in many circumstances, necessary to have access to information, technological innovation, resources, and opportunities 
(Glavee-Geo, 2019; Pulles et al., 2016; Walter et al., 2001). For example, Walmart often uses its domain to get better prices from its suppliers, and yet, compared to smaller retailers, it offers suppliers better opportunities for growth in terms of market share. This situation, in turn, can result in supplier satisfaction since business growth is a key factor for the supplier. In this sense, high levels of mutual dependence are desirable from the perspective of satisfaction, while the lack of dependence is associated with low supplier satisfaction.

In the logistics services industry, the relationships between shipper and 3PL are characterized by intermediate levels of mutual dependence. 3PL has a strategic role in its customers' operations because of the complexity of the services due to its very nature and the level of customization required in solving the problems. For example, in a severe logistical failure in KFC, in the United Kingdom, a new partner in the chain was unable to deliver on time and according to quality criteria, leading to the interruption of the operation of its 900 stores. The inherent characteristics of providing services suggest that a greater value can be obtained from a more intertwined relational exchange. Customers often find it difficult to assess the capacity, offerings, and quality of service of potential alternative providers; therefore, customers are strongly motivated to maintain satisfactory and successful relationships to minimize costs with the end of the relationship.

A dominant position can be used to influence the partner's behavior in the relationship. However, it is advisable for managers to avoid using coercive methods and to use reward mechanisms. This behavior will lead to the 3PL's satisfaction, which in itself is related to several positive results for shippers and 3PL. A dominant position can be used to provide guidance and direction on projects collaboratively. Dominant managers are advised to use their company's dominant position in a non-coercive and rewarding manner. For example, the best suppliers receive the annual awards offered by automakers (Toyota, Honda, and General Motors) to suppliers for achieving desired results. In this situation, the supplier that is recognized as prized tends to develop mutual empathy with the partner, starting to be remembered as the 'supplier of excellence.' This behavior can lead to supplier satisfaction, which is related to several positive results for the relationship between buyers and suppliers. In turn, this can be an opportunity to develop a closer relationship with the most powerful partner by promoting interpersonal attraction or gratitude.

\section{CONCLUSIONS}

This study sought to answer the following research question: What are the effects of benefit-based dependence between customer and supplier and supplier satisfaction? The results indicate that mutual dependence is positively related to supplier satisfaction, but, surprisingly, dependence asymmetry can also be related to higher supplier satisfaction levels. The research was guided by previous studies' recommendations regarding the distinction between mutual dependence and dependence asymmetry, since many studies assume different effects for each of the constructs. The effects of asymmetry in a relationship are not always direct because having a position of power over a partner does not necessarily imply exercising that power, especially in situations where there are moderate levels of mutual dependence. The use of power by a dominant partner can lead to the dissatisfaction of the dependent partner, while the non-use of power leads to the satisfaction of the dependent partner. Therefore, even though dependence asymmetry may implicitly suggest the use of power, this may not be the case. When the partners understand that the relationship provides benefits that are difficult to replace, threats and punishments increase the risk of retaliation and non-collaborative behavior by the most dependable partners. On the other hand, the supplier may be in a relationship in which the supplier is more dependent but still satisfied due to the advantages achieved - for example, due to increased sales volume, stable revenues, customer-led innovation, learning best practices, accurate and timely information, stable demand, and support for operational development.

The results of this study must be seen in the light of some limitations. First, as the focus of this research was on identifying the effects of dependence between shipper and $3 \mathrm{PL}$ and $3 \mathrm{PL}$ satisfaction, it was structured to capture the two parts of the dyad's perception. However, due to low adherence, only the 3PLs' perceptions were captured. Therefore, although this work is in line with other studies on interdependence and outsourcing, a dyadic survey would capture a more holistic reality of these differences in perception and how they can affect 3PL satisfaction. Similar to other studies on buyer-supplier relationships, a cross-sectional research plan was adopted in this work. Although satisfaction has been examined in the dyadic environment, changes in perception have not been captured over time. A longitudinal study can be useful to examine important changes in the relationship structure and how it affects satisfaction. Finally, future studies can examine the influence of financial dependence on 3PL satisfaction. 


\section{REFERENCES}

Ambrose, E., Marshall, D., \& Lynch, D. (2010). Buyer supplier perspectives on supply chain relationships. International Journal of Operations of Production Management, 30(12), 1269-1290. https://doi.org/10.1108/01443571011094262

Bagozzi, R. P., Yi, Y., \& Phillips, L. W. (1991). Assessing construct validity in organizational research. Administrative Science Quarterly, 36(3), 421-458. https://doi.org/10.2307/2393203

Barranti, M., Carlson, E. N., \& Côté, S. (2017). How to test questions about similarity in personality and social psychology research: Description and empirical demonstration of response surface analysis. Social Psychological and Personality Science, 8(4), 465-475. https://doi.org/10.1177/1948550617698204

Bauman, K. E., \& Dent, C. W. (1982). Influence of an objective measure on self-reports of behavior. Journal of Applied Psychology, 67(5), 623-628. https://doi.org/10.1037/0021-9010.67.5.623

Benton, W. C., \& Maloni, M. J. (2005). The influence of power driven buyer/seller relationships on supply chain satisfaction. Journal of Operations Management, 23(1), 1-22. https://doi.org/10.1016/j.jom.2004.09.002

Blau, P. M. (1964). Exchange and power in social life. New York, NY: John Wiley.

Brito, R. P., \& Miguel, P. L. S. (2017). Power, governance, and value in collaboration: Differences between buyer and supplier perspectives. Journal of Supply Chain Management, 53(2), 61-87. https://doi.org/10.1111/jscm.12134

Caniëls, M. C. J., Vos, F. G. S., Schiele, H., \& Pulles, N. J. (2018). The effects of balanced and asymmetric dependence on supplier satisfaction: Identifying positive effects of dependency. Journal of Purchasing and Supply Management, 24(4), 343-351. https://doi.org/10.1016/j.pursup.2017.11.003

Casciaro, T., \& Piskorski, M. J. (2005). Power imbalance, mutual dependence, and constraint absorption: A closer look at resource dependence theory. Administrative Science Quarterly, 50(2), 167-199. https://doi.org/10.2189/asqu.2005.50.2.167

Cook, K. S., Cheshire, C., \& Gerbasi, A. (2006). Power, dependence and social exchange. In P. J. Burke (Ed.), Contemporary social psychological theories (pp. 194-215). Stanford, CA: Stanford University Press

Crook, T. R., \& Combs, J. G. (2007). Sources and consequences of bargaining power in supply chains. Journal of Operations Management, 25(2), 546-555. https://doi.org/10.1016/j.jom.2006.05.008

Crook, T. R., Craighead, C. W., \& Autry, C. W. (2017). Hold back or held back? The roles of constraint mitigation and exchange diffusion on power "nonuse" in buyer-supplier exchanges. Journal of Supply Chain Management, 53(2), 10-21. https://doi.org/10.1111/jscm.12135
Dwyer, F. R., Schurr, P. H., \& Oh, S. (1987). Developing buyerseller relationships. Journal of Marketing, 51(2), 11-27. https://doi.org/10.2307/1251126

Edwards, J. R. (2002). Alternatives to difference scores: Polynomial regression analysis and response surface methodology. In F. Drasgow \& N. Schmitt (Eds.), The Jossey-Bass business o management series. Measuring and analyzing behavior in organizations: Advances in measurement and data analysis (pp. 350-400). San Francisco, CA: Jossey-Bass.

Emerson, R. M. (1962). Power-dependence relations. American Sociological Review, 27(1), 31-41. https://doi.org/10.2307/2089716

Farh, J.-L., Werbel, J. D., \& Bedeian, A. G. (1988). An empirical investigation of self- appraisal-based performance evaluation. Personnel Psychology, 41(1), 141-156. https://doi.org/10.1111/j.1744-6570.1988.tb00636.x

Fundação Dom Cabral (2018). Perfil dos operadores logísticos no Brasil relatório analitico. Retrieved from https://old.abolbrasil.org.br/pdf/1554746504.pdf

Flynn, B., Pagell, M., \& Fugate, B. (2018). Editorial: Survey research design in supply chain management: The need for evolution in our expectations. Journal of Supply Chain Management, 54(1), 1-15. https://doi.org/10.1111/jscm.12161

Forza, C. (2002). Survey research in operations management: A process-based perspective. International Journal of Operations \& Production Management, 22(2), 152-194. https://doi.org/10.1108/01443570210414310

Gaski, J. F. (1984). The theory of power and conflict in channels of distribution. Journal of Marketing, 48(3), 9-29. https://doi.org/10.2307/1251326

Gassenheimer, J. B., \& Ramsey, R. (1994). The impact of dependence on dealer satisfaction: A comparison of reseller-supplier relationships. Journal of Retailing, 70(3), 253-266. https://doi.org/10.1016/0022-4359(94)90035-3

Glavee-Geo, R. (2019). Does supplier development lead to supplier satisfaction and relationship continuation? Journal of Purchasing and Supply Management, 25(3), 100537. https://doi.org/10.1016/j.pursup.2019.05.002

Griffith, D. A., Hoppner, J. J., Lee, H. S., \& Schoenherr, T. (2017). The influence of the structure of interdependence on the response to inequity in buyer-supplier relationships. Journal of Marketing Research, 54(1), 124-137. https://doi.org/10.1509/jmr.13.0319

Gulati, R., \& Sytch, M. (2007). Dependence asymmetry and joint dependence in interorganizational relationships: Effects of embeddedness on a manufacturer's performance in procurementrelationships. AdministrativeScience Quarterly, 52(1), 32-69. https://doi.org/10.2189/asqu.52.1.32

Gundlach, G. T., \& Cadotte, E. R. (1994). Exchange interdependence and interfirm interaction: Research in a simulated channel setting. Journal of Marketing Research, 31(4), 516-532. https://doi.org/10.2307/3151880 
Hair, J. F., Black, W. C., Babin, B. J., \& Anderson, R. E. (2014). Multivariate data analysis. Harlow, UK: Pearson.

Handley, S. M., \& Benton, W. C. (2012). Mediated power and outsourcing relationships. Journal of Operations Management, 30(3), 253-267. https://doi.org/10.1016/j.jom.2011.11.004

Handley, S. M., Jong, J., \& Benton, W. C. (2019). How service provider dependence perceptions moderate the poweropportunism relationship with professional services. Production and Operations Management, 28(7), 16921715. https://doi.org/10.1111/poms.13013

Hillman, A. J., Withers, M. C., \& Collins, B. J. (2009). Resource dependence theory: A review. Journal of Management, 35(6), 1404-1427. https://doi.org/10.1177/0149206309343469

Hofer, A. R. (2015). Are we in this together? The dynamics and performance implications of dependence asymmetry and joint dependence in logistics outsourcing relationships. Transportation Journal, 54(4), 438-472. https://doi.org/10.5325/transportationj.54.4.0438

Huo, B., Flynn, B. B., \& Zhao, X. (2017). Supply chain power configurations and their relationship with performance. Journal of Supply Chain Management, 53(2), 88-111. https://doi.org/10.1111/jscm.12139

Huo, B., Liu, C., Chen, H., \& Zhao, X. (2017). Dependence, trust, and 3PL integration: An empirical study in China. International Journal of Physical Distribution \& Logistics Management, 47(9), 927-948. https://doi.org/10.1108/IJPDLM-09-2016-0284

Huo, B., Tian, M., Tian, Y., \& Zhang, Q. (2019). The dilemma of inter-organizational relationships: Dependence, use of power and their impacts on opportunism. International Journal of Operations \& Production Management, 39(1), 2-23. https://doi.org/10.1108/IJOPM-07-2017-0383

Huo, B., Wang, Q., Zhao, X., \& Schuh, S. (2016). Threats and benefits of power discrepancies between organisations: A supply chain perspective. International Journal of Production Research, 54(13), 3870-3884. https://doi.org/10.1080/00207543.2016.1159744

ILOS. (2014). Tercerizaçâa logistica no Brasil. Retrieved from http:// www.ilos.com.br/web/analise-de-mercado/relatorios-depesquisa/terceirizacao-logistica-no-brasil-panorama

Ireland, R. D., \& Webb, J. W. (2007). A multi-theoretic perspective on trust and power in strategic supply chains. Journal of Operations Management, 25(2), 482-497. https://doi.org/10.1016/j.jom.2006.05.004

Kim, Y., \& Choi, T. Y. (2018). Tie strength and value creation in the buyer-supplier context: A u-shaped relation moderated by dependence asymmetry. Journal of Management, 44(3), 1029-1064. https://doi.org/10.1177/0149206315599214

Kim, S. K., \& Hsieh, P.-H. (2003). Interdependence and its consequences in distributor-supplier relationships: A distributor perspective through response surface approach. Journal of Marketing Research, 4O(1), 101-112. https://doi.org/10.1509/jmkr.40.1.101.19130
Kline, R. B. (2011). Principles and practice of structural equation modeling. New York: Guilford Press

Kull, T. J., \& Ellis, S. C. (2016). Coping with dependence: A logistics strategy based on interorganizational learning for managing buyer-supplier relations. Journal of Business Logistics, 37(4), 346-363. https://doi.org/10.1111/jbl.12146

Kumar, N., Scheer, L. K., \& Steenkamp, J.-B. E. M. (1995). The effects of perceived interdependence on dealer attitudes. Journal of Marketing Research, 32(3), 348-356. https://doi.org/10.2307/3151986

Kumar, N., Scheer, L. K., \& Steenkamp, J.-B. E. M. (1998). Interdependence, punitive capability, and the reciprocation of punitive actions in channel relationships. Journal of Marketing Research, 35(2), 225-235. https://doi.org/10.2307/3151850

Leonidou, L. C., Talias, M. A., \& Leonidou, C. N. (2008). Exercised power as a driver of trust and commitment in cross-border industrial buyer-seller relationships. Industrial Marketing Management, 37(1), 92-103. https://doi.org/10.1016/j.indmarman.2007.08.006

Leuschner, R., Carter, C. R., Goldsby, T. J., \& Rogers, Z. S. (2014). Third-party logistics: A meta-analytic review and investigation of its impact on performance. Journal of Supply Chain Management, 50(1), 21-43. https://doi.org/10.1111/jscm.12046

Lieb, R. C., \& Lieb, K. J. (2016). 3PL CEO perspectives on the current status and future prospects of the thirdparty logistics industry in North America: The 2014 survey. Transportation Journal, 55(1), 78-92. https://doi.org/10.5325/transportationj.55.1.0078

Manders, J. H. M., Caniëls, M. C. J., \& Ghijsen, P. W. T. (2017). Supply chain flexibility: A systematic literature review and identification of directions for future research. The International Journal of Logistics Management, 28(4), 9641026. https://doi.org/10.1108/IJLM-07-2016-0176

Marasco, A. (2008). Third-party logistics: A literature review. International Journal of Production Economics, 113(1), 127-147. https://doi.org/10.1016/j.ijpe.2007.05.017

Molm, L. D. (1991). Affect and social exchange: Satisfaction in power-dependence relations. American Sociological Review, 56(4), 475-493. https://doi.org/10.2307/2096269

Moore, G. C., \& Benbasat, I. (1991). Development of an instrument to measure the perceptions of adopting an information technology innovation. Information Systems Research, 2(3), 173-239. https://doi.org/10.1287/isre.2.3.192

Nyaga, G. N., Lynch, D. F., Marshall, D., \& Ambrose, E. (2013). Power asymmetry, adaptation and collaboration in dyadic relationships involving a powerful partner. Journal of Supply Chain Management, 49(3), 42-65. https://doi.org/10.1111/jscm.12011

Pfeffer, J., \& Salancik, G. (1978). The external control oforganizations: A resource dependence perspective. New York: Harper \& Row. 
Podsakoff, P. M., MacKenzie, S. B., Lee, J.-Y., \& Podsakoff, N. P. (2003). Common method biases in behavioral research: A critical review of the literature and recommended remedies. Journal of Applied Psychology, 88(5), 879-903. https://doi.org/10.1037/0021-9010.88.5.879

Podsakoff, P. M., \& Organ, D. W. (1986). Self-reports in organizational research: Problems and prospects. Journal of Management, 12(4), 531-544. https://doi.org/10.1177/014920638601200408

Prajogo, D., Chowdhury, M., Nair, A., \& Cheng, T. C. E. (2020). Mitigating the performance implications of buyer's dependence on supplier: The role of absorptive capacity and long-term relationship. Supply Chain Management, 25(6), 693-707. https://doi.org/10.1108/SCM-07-2019-0254

Pulles, N. J., Schiele, H., Veldman, J., \& Hüttinger, L. (2016). The impact of customer attractiveness and supplier satisfaction on becoming a preferred customer. Industrial Marketing Management, 54, 129-140. https://doi.org/10.1016/j.indmarman.2015.06.004

Reimann, F., \& Ketchen, D. J. (2017). Power in supply chain management. Journal of Supply Chain Management, 53(2), 3-9. https://doi.org/10.1111/jscm.12140

Scheer, L. K., Miao, C. F., \& Garrett, J. (2010). The effects of supplier capabilities on industrial customers' loyalty: The role of dependence. Journal of the Academy of Marketing Science, 38(1), 90-104. https://doi.org/10.1007/s11747-008-0129-6

Scheer, L. K., Miao, C. F., \& Palmatier, R. W. (2015). Dependence and interdependence in marketing relationships: Meta-analytic insights. Journal of the Academy of Marketing Science, 43(6), 694-712. https://doi.org/10.1007/s11747-014-0418-1

Schönbrodt, F. D., Humberg, S., \& Nestler, S. (2018). Testing similarity effects with dyadic response surface analysis. European Journal of Personality, 32(6), 627-641. https://doi.org/10.1002/per.2169
Schwieterman, M. A., Miller, J., Knemeyer, A. M., \& Croxton, K. L. (2020). Do supply chain exemplars have more or less dependent suppliers? Journal of Business Logistics, 41(2), 149-173. https://doi.org/10.1111/jbl.12249

Shanock, L. R., Baran, B. E., Gentry, W. A., Pattison, S. C., \& Heggestad, E. D. (2010). Polynomial regression with response surface analysis: A powerful approach for examining moderation and overcoming limitations of difference scores. Journal of Business and Psychology, 25(4), 543-554. https://doi.org/10.1007/s10869-010-9183-4

Shu, E., \& Lewin, A. Y. (2017). A resource dependence perspective on low-power actors shaping their regulatory environment: The case of Honda. Organization Studies, 38(8), 10391058. https://doi.org/10.1177/0170840616670432

Tabachnick, B. G., \& Fidell, L. S. (2012). Using multivariate statistics (6th ed.). New York: Harper \& Row.

Vázquez-Casielles, R., Iglesias, V., \& Varela-Neira, C. (2017). Manufacturer-distributor relationships: Role of relationship-specific investment and dependence types. Journal of Business \& Industrial Marketing, 32(8), 12451260. https://doi.org/10.1108/JBIM-10-2016-0244

Walter, A., Ritter, T., \& Gemünden, H. G. (2001). Value creation in buyer-seller relationships: Theoretical considerations and empirical results from a supplier's perspective. Industrial Marketing Management, 30(4), 365-377. https://doi.org/10.1016/S0019-8501(01)00156-0

Zou, S., Taylor, C. R., \& Osland, G. E. (1998). The EXPERF scale: A cross-national generalized export performance measure. Journal of International Marketing, 6(3), 37-58. https://doi.org/10.1177/1069031X9800600307 


\section{Authorship}

\section{Antonio Carlos Rodrigues*}

Universidade Federal de Juiz de Fora, Faculdade de Administração e Ciências Contábeis

Av. Dr. Raimundo Monteiros Rezende, no 330, Centro, 35010177, Governador Valadares, MG, Brazil.

E-mail address: antonio.rodrigues@facc.uff.br

(1) https://orcid.org/0000-0003-2308-4625

\section{Ricardo Silveira Martins}

Universidade Federal de Minas Gerais, Faculdade de Ciências Econômicas

Av. Pres. Antônio Carlos, no 6627, Pampulha, 31270-901, Belo Horizonte, MG, Brazil.

E-mail: rmartins@face.ufmg.br, ricardomartins.ufmg@gmail.com

(1) https://orcid.org/0000-0001-9717-3896

* Corresponding Author

\section{Funding}

The authors reported that this paper was written with the financial support from CAPES (Coordination of Superior Level Staff Improvement).

\section{Conflict of Interests}

The authors have stated that there is no conflict of interest.

\section{Peer Review Method}

This content was evaluated using the double-blind peer review process. The disclosure of the reviewers' information on the first page, as well as the Peer Review Report, is made only after concluding the evaluation process, and with the voluntary consent of the respective reviewers and authors.

\section{Authors' Contributions}

$1^{\text {st }}$ author: conceptualization (lead); data curation (equal); formal analysis (equal); investigation (lead); methodology (lead); project administration (equal); software (lead); writing-original draft (equal); writing-review \& editing (equal).

$2^{\text {nd }}$ author: conceptualization (supporting); formal analysis (supporting); project administration (supporting); supervision (lead); writing-original draft (equal); writingreview \& editing (supporting).

\section{Copyrights}

RAC owns the copyright to this content.

\section{Plagiarism Check}

The RAC maintains the practice of submitting all documents approved for publication to the plagiarism check, using specific tools, e.g.: iThenticate.

\section{Data Availability}

The authors chose not to share their database and claim that they do so, given that, as informed to the participants, under no circumstances would the data generated in the survey be disclosed. It was also ensured that only the statistical results consolidated data would be disseminated for academic purposes, and this information will be presented through tables, figures, or graphs. The authors also state that the data are unpublished and will produce other papers in the future. RAC encourages data sharing but, in compliance with ethical principles, it does not demand the disclosure of any means of identifying research subjects, preserving the privacy of research subjects. The practice of open data is to enable the reproducibility of results, and to ensure the unrestricted transparency of the results of the published research, without requiring the identity of research subjects. 